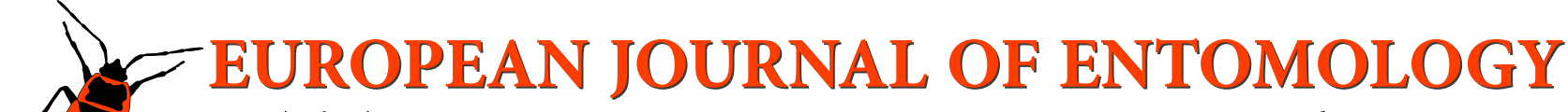 \\ ISSN (online): 1802-8829 \\ http://www.eje.cz \\ Eur. J. Entomol. 117: 243-251, 2020 \\ doi: 10.14411/eje.2020.026 \\ ORIGINAL ARTICLE
}

\section{Nesting ecology of Polistes gallicus (Hymenoptera: Vespidae) in South-Western Spain}

\author{
José Luis PÉREZ-BOTE ${ }^{1}$, CARlos MORA-RUBIO $^{1}$, Josefa LÓPEZ MARTíNeZ² and Tomás RODRíGUeZ RIAÑO² \\ ${ }^{1}$ Department of Zoology, Faculty of Sciences, University of Extremadura, Av. de Elvas s/n, 06006 Badajoz, Spain; e-mails: \\ jlperez@unex.es, morarubio@unex.es \\ ${ }^{2}$ Department of Botany, Faculty of Sciences, University of Extremadura, Av. de Elvas s/n, 06006 Badajoz, Spain; e-mails: \\ josefalopez@unex.es, trodri@unex.es
}

Key words. Hymenoptera, Vespidae, Polistes gallicus, nesting ecology, plant species, nest orientation, water distance, simple founding, Spain

\begin{abstract}
Among the numerous factors that contribute to the success of social wasps, colony productivity is the most important and depends on ecological and environmental factors, such as the nest site. Consequently, nest-site choice should be determined by nest-site characteristics. The objective of this study was to determine on which species of plants Polistes gallicus wasps build their nests and identify the possible preferred features of plants used during nest-site selection by the foundress. From February to October 2017-2019 we recorded details of the nests in natural areas in south-western Spain (at $38^{\circ}$ latitude). Nests of $P$. gallicus were recorded on 49 species of plants belonging to 23 families, with Scirpoides holoschoenus, Epilobium hirsutum and Foeniculum vulgare the most common. Significantly more wasps built their nests on herbaceous than on shrub and arboreal plants, and on "green" than "brown-grey" plants. Most of the nests were 21 to $189 \mathrm{~cm}$ above the ground, with a nest azimuth of about $102^{\circ}$. Nests were located at a mean distance of $43.51 \pm 123.79 \mathrm{~m}$ from the nearest source of water. The length of the nesting season in the area studied was between 30 and 33 weeks, and more colonies were founded by a single foundress than several foundresses. Furthermore, a greater percentage of the single foundress colonies failed than of the multiple-foundress colonies.
\end{abstract}

\section{INTRODUCTION}

Among the numerous factors that contribute to the success of social wasps, colony productivity is the most important. Productivity depends on ecological factors, including temperature, prey availability and number of founders (Gamboa et al., 2005). Colony success and productivity may also be related to environmental factors, for example, nesting site, as reported by Inagawa et al. (2001) and Nadeau \& Stamp (2003) in Polistes snelleni (Saussure) and Polistes fuscatus (Fabricius), respectively. Nest-site selection is closely associated with fitness because of its effect on offspring production. Consequently, choice of a nest-site should be determined by particular nest-site characteristics. Thus, habitat characteristics that influence the probability of nest predation may be particularly important because nest predation is often the primary cause of nest mortality in polistine wasps (Cervo \& Turillazzi, 1985).

In bird assemblages, nests may be affected by habitat at two spatial scales (Martin \& Roper, 1988): the nest site (characteristics of the immediate vicinity of the nest) and the nest patch (characteristics of the habitat surrounding the nest). Previous studies on polistine wasps have focused on the nest site, examining mainly nest site selection and orientation. However, the nest patch may be equally important to the selection of sites for nesting, as is reported for bird assemblages (Martin \& Roper, 1988). For example, foliage density in the nest patch may impede random and intentional nest discovery by predators by obstructing visual cues. An alternative hypothesis that may operate simultaneously or independently is that predation probability may decrease with increase in density of particular types of foliage used as nest sites; such increases may reflect the number of potential nest sites that predators must examine, which reduces their chances of finding a nest. Prey availability is another factor that affects colony development. Eusocial vespids are opportunistic, generalist foragers. However, individual social wasps often return to hunt at sites where they were previously successful and feed repeatedly on the same species of prey, thus functioning individually as facultative specialists (Raveret, 2000), so the choice of hunting sites can be influenced by prey density. It is known that plant architecture and structural heterogeneity may affect the distribution and abundance of arthropods. According to Root (1973), increased structural heterogeneity of vegetation may increase the number of niches available for consumers and thus enhance local 
species richness. The relationship between plant species diversity and vegetation structure on invertebrate diversity has been studied, for example, in butterflies (Collinge et al., 2003), one of the preferred prey species (caterpillars) of wasps. These authors report that habitat quality positively affects butterfly species richness and composition. Water can also be a limiting resource for wasps (Raveret, 2000). In addition to imbibing water or passing it to larvae (Raveret, 2000), social wasps mix water with masticated plant fibre when processing material for nest construction and use it in conjunction with wing fanning in the evaporative cooling of the nest (Steiner, 1930; Heinrich, 1993; Höcherl et al., 2016). Kasuya (1982) demonstrate that in Polistes chinensis antennalis, the rate of water intake decreased as the distance to the water source increased and Horwood et al. (1993) point out that water is an important factor limiting the spread of Vespula germanica in Australia.

In natural environments, polistine wasps build their nests almost exclusively on plants. Cervo \& Turillazi (1985) state that the nests of $P$. nimpha are built predominantly on shrubs of Inula viscosa (Asteraceae). Rusina (2006, 2009) provides information about the species of plants utilised by $P$. dominula in the Ukraine, where the paper wasps build their nests on plants such as Elytrigia elongata, Phragmites australis, Artemisia marschalliana, A. austriaca, Tanacetum vulgare, Lythrum salicaria, Pyrus communis, Prunus spinosa, Grindelia squarrosa, Eryngium campestre, Melilotus albus and Centaurea diffusa. Kozyra et al. (2016) report that foundresses of $P$. nimpha prefer to nest in particular species of plants, at a particular height above the ground with the combs at a particular geographic orientation (azimuth). The first two factors are important in terms of maximizing the chances of colony survival in the pre-emergence phase, the most dangerous initial part of a colony's life cycle, while the azimuth is most likely important for nest thermoregulation when the surrounding vegetation is still low and the nest is directly exposed to sunlight. These authors report that nests are most often initiated on Hypericum, Tanacetum, Daucus and Achillea plants.

In the Old World, Polistes gallicus (L., 1767) is, without doubt, one of the most abundant species of Polistes. It occurs in the Western and Central Mediterranean area, eastwards to the Greek island of Corfu; in North-Western Africa, from Tunisia to Morocco; and northwards to the Italian Alps and Southern Switzerland (Schmid-Egger et al., 2017). It is particularly abundant in countries around the Mediterranean basin and in North African countries. According to Schmid-Egger et al. (2017), seven species of Polistes are present on the Iberian Peninsula, with $P$. gallicus and $P$. dominula the most abundant species in the South, where both species are common in natural and urban environments (Gayubo \& Torres, 1990).

There is only information on the nesting sites of paper wasps on the Iberian Peninsula for P. dominula and records of the plants it nests on are scattered in various publications and mostly in the description of the area studied (Cant et al., 2006; Zanette \& Field, 2008, 2011; Leadbeater et al.,
2010). All these authors mention that the nests of $P$. dominula are in hedges of prickly pear cactus (Opuntia sp.). There is no information on the species of plants utilised by $P$. gallicus. Thus, the aim of this study was to determine on which species of plants $P$. gallicus build their nests and identify the features of species of plants foundresses respond to when selecting a nest site. We also considered the height at which the nest was located and its orientation in relation to north (azimuth). In addition, we investigated the foundation of colonies of $P$. gallicus in natural environments in South-Western Spain.

\section{MATERIALS AND METHODS}

\section{Study site}

Fieldwork was carried out in the Llanos de Olivenza area near the city of Olivenza (South-Western Spain, 38 $41^{\prime} 0.7^{\prime \prime} \mathrm{N} /$ $7^{\circ} 06^{\prime} 0.1^{\prime \prime} \mathrm{W}, 267 \mathrm{~m}$ a.s.1.) from February to October 2017, 2018 and 2019. The climate is typically Continental-Mediterranean, with relatively cold wet winters and dry hot summers. During the period studied, mean annual temperatures were above the historical average (Fig. 1), while rainfall was below the historical average (mean temperature: $16.3^{\circ} \mathrm{C}$, rainfall: $432 \mathrm{~mm}$ yr-1, Capel Molina, 1981). The flat-to-gently undulating landscape is dominated by a mosaic of dry winter cereal crops, olive groves and vineyards. In this area, natural habitats only occur in field margins, some patches of riparian vegetation and holm oak (Quercus ilex ssp. ballota) dehesas (an agro-silvo pastoral system).

\section{Location of nests}

We started the field research in early February at twelve different sites near Olivenza (within a $15 \mathrm{~km}$ radius). We searched for nests in favourable habitats (Fig. 2) and marked each nest with an adhesive plastic band (the marks were placed on the stem nearest to the nest). The location was also recorded using GPS (Garmin). Next, we recorded the species of plant and measured the height at which the nest was located and its orientation in relation to north (azimuth). We measured nest height as the distance between the ground and the petiole of the nest. Using a digital compass we recorded the angle between a line oriented towards the magnetic north and the axis of the petiole of each wasp's nest. In the laboratory, we measured the distance from the nest to the nearest source of water (small streams in most cases) using SIGPAC (the Span-

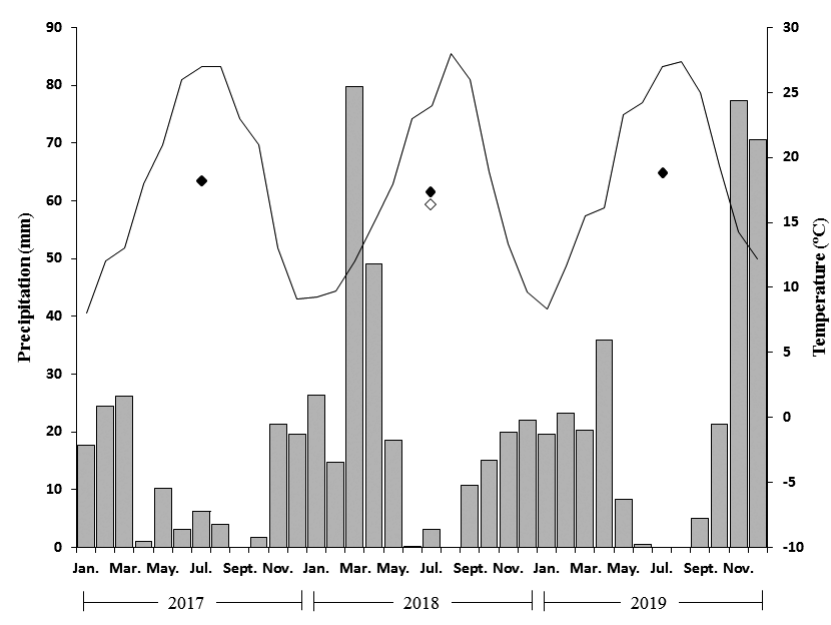

Fig. 1. Precipitation and temperatures recorded during the period studied. The black symbols are average annual temperatures and white symbol the average annual temperature based on historical data. Source: National Institute of Meteorology (Madrid). 

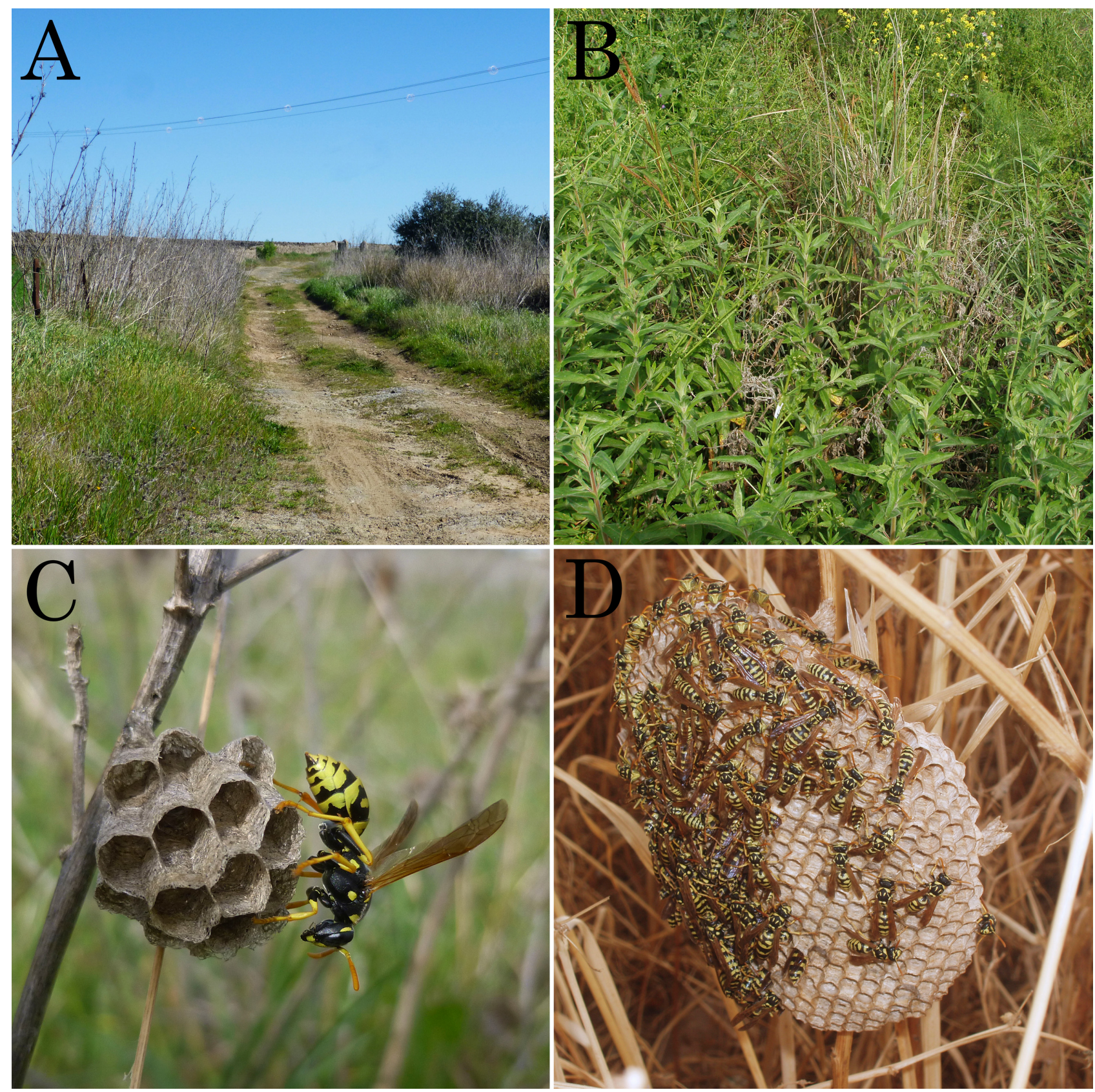

Fig. 2. Main habitats of $P$. gallicus in the southwest of Spain. A - crop margins where Foeniculum vulgare is the dominant species; $\mathrm{B}-$ areas near watercourses where Dittrichia viscosa and Scirpoides holoschoenus are the most abundant species; $\mathrm{C}-$ nests of $P$. gallicus on F. vulgare (early spring) and D - on Chrysanthemum coronarium (late summer).

ish version of the European Land Parcels Information System, LPIS-CAP. Provided by the Spanish Ministry of Agriculture).

Plants were identified in situ or in the laboratory according to Flora iberica (Castroviejo, 1986-2012). For each plant, the following data were recorded: type (arboreal, shrubby, herbaceous), life form according to Raunkiaer (1934), stem colour (green, grey, brown), presence of defences (thorns, spines, hairs) and subjectively estimated the density of stems or leaves (low, medium, high). Wasps were identified using the identification key of Schmid-Egger et al. (2017).

\section{Nest productivity}

The number of foundresses was recorded when each nest was located and verified during the following weeks until the first workers emerged. At the end of the founding period, we recorded the number of intact nests and compared the percentage survival of those that were established by different numbers of foundresses. A nest was classified as failed if all the foundresses disappeared during the founding period and no adults emerged from the nest (Tibbetts \& Reeve, 2003).

\section{Statistical analysis}

The preferences for nesting on different plants and their characteristics were tested using $X^{2}$ tests. The differences in nest height and distance to a source of water between years were tested using the Mann-Whitney U test. We used Program ORIANA (Kovach, 2011) to calculate circular statistics for nest orientation: mean vector and standard error. Rayleigh's test of uniformity was used to test mean exposures for non-random orientations (Batschelet, 1981). The concentration (r) or length of the mean vector calcu- 
Table 1. List of species of plants on which paper wasps nests were recorded in 2017-2019.

\begin{tabular}{|c|c|c|c|c|c|c|}
\hline Plant & Family & Type & Life form & Stem colour & Defence & $\begin{array}{c}\text { Density stems/ } \\
\text { leaves }\end{array}$ \\
\hline Agave americana $\mathrm{L}$. & Agavaceae & shrub & Chamaephyte & green & thorns & high \\
\hline Yucca filamentosa $\mathrm{L}$. & Agavaceae & shrub & Perinneal & green & spines & low \\
\hline Foeniculum vulgare Mill. & Apiaceae & herbaceous & Hemicryptophyte & grey-brown & none & high \\
\hline Hedera helix L. & Araliaceae & shrub & Liana & green & none & high \\
\hline Crepis vesicaria L. & Asteraceae & herbaceous & Therophyte & green & none & low \\
\hline Cichorium intybus L. & Asteraceae & herbaceous & Hemicryptophyte & grey & none & low \\
\hline Dittrichia viscosa (L.) Greuter & Asteraceae & herbaceous & Chamaephyte & green & none & medium \\
\hline Coleostephus myconis (L.) Rchb.f. & Asteraceae & herbaceous & Therophyte & green & none & low \\
\hline Sonchus oleraceus L. & Asteraceae & herbaceous & Therophyte & green & none & low \\
\hline Calendula arvensis L. & Asteraceae & herbaceous & Therophyte & green & none & low \\
\hline Carlina corymbosa L. & Asteraceae & herbaceous & Hemicryptophyte & grey (dry) & thorns & low \\
\hline Scolymus hispanicus L. & Asteraceae & herbaceous & Hemicryptophyte & green & thorns & low \\
\hline Silybum marianum (L.) Gaertn. & Asteraceae & herbaceous & Hemicryptophyte & green & spines & low \\
\hline Chrysanthemum coronarium L. & Asteraceae & herbaceous & Therophyte & green & none & medium \\
\hline Galactites tomentosa Moench & Asteraceae & herbaceous & Therophyte & green & thorns & medium \\
\hline Borago officinalis L. & Boraginaceae & herbaceous & Therophyte & grey (dry) & none & low \\
\hline Echium plantagineum L. & Boraginaceae & herbaceous & Hemicryptophyte & green & setae & medium \\
\hline Diplotaxis virgata (Cav.) DC. & Brassicaceae & herbaceous & Therophyte & green & hairs & low \\
\hline Diplotaxis erucoides (L.) DC. & Brassicaceae & herbaceous & Therophyte & green & hairs & low \\
\hline Sinapis arvensis L. & Brassicaceae & herbaceous & Ther & green & hairs & low \\
\hline Opuntia maxima Miller & Cactaceae & shrub & Chamaephyte & green & thorns & low \\
\hline Dipsacus fullonum L. & Dipsacaceae & herbaceous & Hemicryptophyte & brown (dry) & thorns & low \\
\hline Cistus salviifolius L. & Cistaceae & shrub & Phanerophyte & green & $\mathrm{n}$ & high \\
\hline Thuja occidentalis L. & Cupressaceae & shrub & Phanerophyte & green & none & high \\
\hline Scirpoides holoschoenus (L.) Soják & Cyperaceae & herbaceous & Geophyte & green-brown-grey & spines & high \\
\hline Eleocharis palustris (L.) Roem. et Schult. & Cyperaceae & herbaceous & Helophyte & green & no & high \\
\hline Carex elata Mack. & Cyperaceae & herbaceous & Helophyte & green & none & high \\
\hline Quercus ilex L. & Fagaceae & arboreal & Phanerophyte & green & none & high \\
\hline Brachypodium retusum (Pers.) Beauv. & Gramineae & herbaceous & $\mathrm{Ge}$ & green & none & high \\
\hline Piptatherum miliaceum (L.) Cosson & Gramineae & herbaceous & $\begin{array}{c}\text { Proto- } \\
\text { Hemicryptophyte }\end{array}$ & grey-brown & none & high \\
\hline Ulex eriocladus C. Vicioso & Leguminosae & shrub & Phanerophyte & green & thorns & high \\
\hline Cytisus striatus (Hill) Rothm. & Leguminosae & shrub & Phanerophyte & green & none & high \\
\hline Cytisus scoparius (L.) Link & Leguminosae & shrub & Phanerophyte & green-grey & none & high \\
\hline Asparagus acutifolius L. & Liliaceae & shrub & Phanerophyte & green & thorns & medium \\
\hline Asparagus aphyllus L. & Liliaceae & shrub & Phanerophyte & green & thorns & medium \\
\hline Lavatera cretica L. & Malvaceae & herbaceous & Therophyte & green & none & medium \\
\hline Jasminum fruticans $\mathrm{L}$. & Oleaceae & shrub & Phanerophyte & green & none & high \\
\hline Epilobium hirsutum L. & Onagraceae & herbaceous & $\begin{array}{c}\text { Proto- } \\
\text { Hemicryptophyte }\end{array}$ & green & none & high \\
\hline Rumex crispus L. & Polygonaceae & herbaceous & $\begin{array}{c}\text { Proto- } \\
\text { Hemicryptophyte }\end{array}$ & brown (dry) & none & low \\
\hline Rosa canina L. & Rosaceae & shrub & Phanerophyte & green & thorns & medium \\
\hline Crataegus monogyna Jacq. & Rosaceae & shrub & Phanerophyte & green & none & medium \\
\hline Rubus ulmifolius Schott & Rosaceae & shrub & Chamaephyte & green & thorns & high \\
\hline Prunus dulcis (Mill.) D.A. Webb & Rosaceae & arboreal & Phanerophyte & green & none & medium \\
\hline Pyrus bourgaeana Decne & Rosaceae & arboreal & Phanerophyte & green & none & medium \\
\hline Galium verrucosum Huds. & Rubiaceae & herbaceous & Therophyte & green & setae & low \\
\hline Verbascum sinuatum L. & Scrophulariaceae & herbaceous & Hemicryptophyte & grey (dry) & none & low \\
\hline Scrophularia canina L. & Scrophulariaceae & herbaceous & Chamaephyte & green & none & low \\
\hline Scrophularia lyrata Willd. & Scrophulariaceae & herbaceous & Chamaephyte & green & none & low \\
\hline Typha dominguensis Pers. & Typhaceae & herbaceous & Helophyte & green & none & low \\
\hline
\end{tabular}

lated using circular methods, ranged from 0 to 1 , and is affected by variation in circular data, sample size and grouping. Values of $r$ near 1 indicate data points closely concentrated near the mean angle or, in our case, nest-sites with a particular direction of orientation. Differences in mean direction between years were analysed using the parametric Watson-Williams F-test in cases where the assumptions underlying this test were fulfilled.

\section{RESULTS}

We located 122 nests of paper wasps in 2017, 106 in 2018 and 133 in 2019. In 2017, nest founding started in the second week of March and ended in the second week of October, in 2018, it started late in March (third week) due to an unusual period of rain and ended in the second week of October. Finally, in 2019, nest founding started in late February and ended in the second week of October, as in previous years. Thus, the length of the season was about 32 weeks in 2017, 30 weeks in 2018 and 33 weeks in 2019.

In total, we found nests of paper wasps on 49 species of plants belonging to 23 families (Table 1), with the family Asteraceae most represented. Paper wasps nested on 18 plants in 2017, 28 in 2018, and 40 in 2019. More wasps 
Table 2. List of species of plants on which paper wasp nests were recorded in 2017-2019.

\begin{tabular}{|c|c|c|c|c|c|c|c|c|}
\hline \multirow{2}{*}{ Plant species } & \multicolumn{4}{|c|}{ Number of nests } & \multicolumn{4}{|c|}{ Percentage use } \\
\hline & 2017 & 2018 & 2019 & All & 2017 & 2018 & 2019 & All \\
\hline Agave americana L. & 6 & 5 & 1 & 12 & 4.92 & 4.72 & 0.75 & 3.32 \\
\hline Yucca filamentosa $\mathrm{L}$. & & & 1 & 1 & & & 0.75 & 0.28 \\
\hline Foeniculum vulgare Mill. & 8 & 5 & 7 & 20 & 6.56 & 4.72 & 5.26 & 5.54 \\
\hline Hedera helix L. & & 1 & 1 & 2 & & 0.94 & 0.75 & 0.55 \\
\hline Crepis vesicaria L. & 8 & 3 & 6 & 17 & 6.56 & 2.83 & 4.51 & 4.71 \\
\hline Cichorium intybus $\mathrm{L}$. & & 1 & 3 & 4 & & 0.94 & 2.26 & 1.11 \\
\hline Dittrichia viscosa (L.) Greuter & & 1 & 3 & 4 & & 0.94 & 2.26 & 1.11 \\
\hline Coleostephus myconis (L.) Rchb.f. & 1 & & & 1 & 0.82 & & & 0.28 \\
\hline Sonchus oleraceus L. & & 4 & 1 & 5 & & 3.77 & 0.75 & 1.39 \\
\hline Calendula arvensis $\mathrm{L}$. & & & 1 & 1 & & & 0.75 & 0.28 \\
\hline Carlina corymbosa L. & & & 5 & 5 & & & 3.76 & 1.39 \\
\hline Scolymus hispanicus L. & & & 1 & 1 & & & 0.75 & 0.28 \\
\hline Silybum marianum (L.) Gaertn. & 1 & & & 1 & 0.82 & & & 0.28 \\
\hline Chrysanthemum coronarium L. & & & 2 & 2 & & & 1.50 & 0.55 \\
\hline Galactites tomentosa Moench & & & 1 & 1 & & & 0.75 & 0.28 \\
\hline Borago officinalis L. & & & 1 & 1 & & & 0.75 & 0.28 \\
\hline Echium plantagineum $\mathrm{L}$. & & & 1 & 1 & & & 0.75 & 0.28 \\
\hline Diplotaxis virgata (Cav.) DC. & & & 2 & 2 & & & 1.50 & 0.55 \\
\hline Diplotaxis erucoides (L.) DC. & & & 1 & 1 & & & 0.75 & 0.28 \\
\hline Sinapis arvensis $\mathrm{L}$. & & & 3 & 3 & & & 2.26 & 0.83 \\
\hline Opuntia maxima Miller & 1 & 3 & 5 & 9 & 0.82 & 2.83 & 3.76 & 2.49 \\
\hline Dipsacus fullonum $\mathrm{L}$. & 3 & 4 & 2 & 9 & 2.46 & 3.77 & 1.50 & 2.49 \\
\hline Cistus salviifolius L. & 1 & & 1 & 2 & 0.82 & & 0.75 & 0.55 \\
\hline Thuja occidentalis L. & & & 1 & 1 & & & 0.75 & 0.28 \\
\hline Scirpoides holoschoenus (L.) Soják & 45 & 34 & 33 & 112 & 36.89 & 32.08 & 24.81 & 31.02 \\
\hline Eleocharis palustris (L.) Roem. et Schult. & 1 & 1 & & 2 & 0.82 & 0.94 & & 0.55 \\
\hline Carex elata Mack. & 8 & 6 & 2 & 16 & 6.56 & 5.66 & 1.50 & 4.43 \\
\hline Quercus ilex L. & & & 12 & 12 & & & 9.02 & 3.32 \\
\hline Brachypodium retusum (Pers.) Beauv. & & 1 & & 1 & & 0.94 & & 0.28 \\
\hline Piptatherum miliaceum (L.) Cosson & & & 2 & 2 & & & 1.50 & 0.55 \\
\hline Ulex eriocladus C. Vicioso & & & 1 & 1 & & & 0.75 & 0.28 \\
\hline Cytisus striatus (Hill) Rothm. & & & 1 & 1 & & & 0.75 & 0.28 \\
\hline Cytisus scoparius (L.) Link & & & 3 & 3 & & & 2.26 & 0.83 \\
\hline Asparagus acutifolius L. & & 1 & 2 & 3 & & 0.94 & 1.50 & 0.83 \\
\hline Asparagus aphyllus $\mathrm{L}$. & & & 1 & 1 & & & 0.75 & 0.28 \\
\hline Lavatera cretica L. & 1 & 1 & 1 & 3 & 0.82 & 0.94 & 0.75 & 0.83 \\
\hline Jasminum fruticans $\mathrm{L}$. & & & 1 & 1 & & & 0.75 & 0.28 \\
\hline Epilobium hirsutum L. & 25 & 22 & 16 & 63 & 20.49 & 20.75 & 12.03 & 17.45 \\
\hline Rumex crispus L. & 2 & 4 & 1 & 7 & 1.64 & 3.77 & 0.75 & 1.94 \\
\hline Rosa canina L. & 3 & 1 & & 4 & 2.46 & 0.94 & & 1.11 \\
\hline Crataegus monogyna Jacq. & & 1 & & 1 & & 0.94 & & 0.28 \\
\hline Rubus ulmifolius Schott & 6 & 4 & 3 & 13 & 4.92 & 3.77 & 2.26 & 3.60 \\
\hline Prunus dulcis (Mill.) D.A. Webb & & & 1 & 1 & & & 0.75 & 0.28 \\
\hline Pyrus bourgaeana Decne & & & 1 & 1 & & & 0.75 & 0.28 \\
\hline Galium verrucosum Huds. & & & 1 & 1 & & & 0.75 & 0.28 \\
\hline Verbascum sinuatum L. & & 1 & & 1 & & 0.94 & & 0.28 \\
\hline Scrophularia canina L. & 1 & 1 & & 2 & 0.82 & 0.94 & & 0.55 \\
\hline Scrophularia lyrata Willd. & 1 & & 1 & 2 & 0.82 & & 0.75 & 0.55 \\
\hline Typha dominguensis Pers. & & 1 & & 1 & & 0.94 & & 0.28 \\
\hline
\end{tabular}

nest on herbaceous than shrubby or arboreal plants $\left(X_{1,0.05}^{2}\right.$ $=4.083, \mathrm{p}=0.043)$, green than brown-grey plants $\left(X_{1,0.05}^{2}\right.$ $=21.33, \mathrm{p}<0.001)$ and plants lacking defences than plants with some type of defence $\left(X_{1,0.05}^{2}=5.33, \mathrm{p}=0.0209\right)$. Finally, no preference was found in relation to the density of stems or leaves $\left(X_{1,0.05}^{2}=0.33, \mathrm{p}=0.5637\right)$ or where the growth point of the plant is located in unfavourable seasons $\left(X_{1,0.05}^{2}=0.16, \mathrm{p}=0.9827\right.$, therophytes, phanerophytes, hemicryptophytes, others). During this study, the most utilised plant for nest building was Scirpoides holoschoenus (31.02\%, Table 2), followed by Epilobium hirsutum (17.45\%), Foeniculum vulgare (5.54\%), Crepis vesicaria $(4.71 \%)$ and Carex elata $(4.43 \%)$. In all cases, nests were located in patches of vegetation and never on isolated plants.

The average height of the nests (Fig. 3) was $75.99 \pm$ $42.06 \mathrm{~cm}$ (range: $21-189 \mathrm{~cm}$ ) in $2017,80.21 \pm 36.77 \mathrm{~cm}$ (range: $23-205 \mathrm{~cm}$ ) in 2018 and $69.93 \pm 38.24 \mathrm{~cm}$ (range: 16-201 cm) in 2019 and did not differ significantly among years (Mann-Whitney test, $U=7.764, p=0.02$ ). The mean overall height of the nests was $75.44 \pm 39.13 \mathrm{~cm}$ (range: $16-205 \mathrm{~cm}$ ). The height of the nests differed significantly between years.

In 2017, the orientation of the paper wasp nests was to the south-east (Fig. 4), with a mean vector of $97.092^{\circ} \pm 27.54^{\circ}$ (circular standard deviation) and a length of mean vector of 


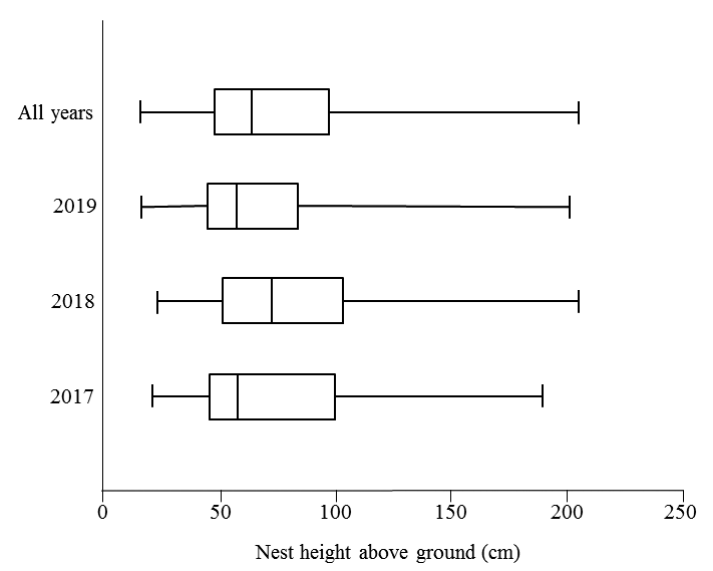

Fig. 3. Heights at which the nests of $P$. gallicus were built in 20172019.

0.891 . In this year, nests were significantly oriented to the east south-east (Raleigh's $Z=84.02, \mathrm{p}<0.001$ ). In 2018, nests were orientated to the south-east (Fig. 4), with a mean vector of $102.96^{\circ} \pm 26.48$ and a length of mean vector of 0.899 . In this year, nests were also significantly oriented to the east south-east (Raleigh's $Z=98.53, \mathrm{p}<0.001$ ). Finally, in 2019, nests were also orientated to the south-east (Fig. 4 ), with a mean vector of $105.07^{\circ} \pm 20.25^{\circ}$ and a length of mean vector of 0.934 . In this year, nests were also significantly oriented to the east south-east (Raleigh's $Z=117.38$, $\mathrm{p}<0.001$ ). Nest orientations differed significantly between years (Watson-Williams F-test, $\mathrm{F}_{2,358}=3.258, \mathrm{p}=0.041$ ). Overall, nests were significantly (Raleigh's $Z=299.308$, $\mathrm{p}<0.0001)$ oriented to the south-east with a mean vector of $102.11^{\circ} \pm 24.80^{\circ}$ and a length of mean vector of 0.911 .

In 2017, paper wasp nests were located $73.97 \pm 140.14$ $\mathrm{m}$ (range: $0.5-552 \mathrm{~m}$ ) from a water source (Fig. 5), in 2018 it was $43.51 \pm 123.59 \mathrm{~m}$ (range: $0.3-760 \mathrm{~m}$ ) and in 2019 it was $32.54 \pm 107.54 \mathrm{~m}$ (range: 0.3-802 m). Overall, the distance between nests and water was $43.51 \pm 123.79$

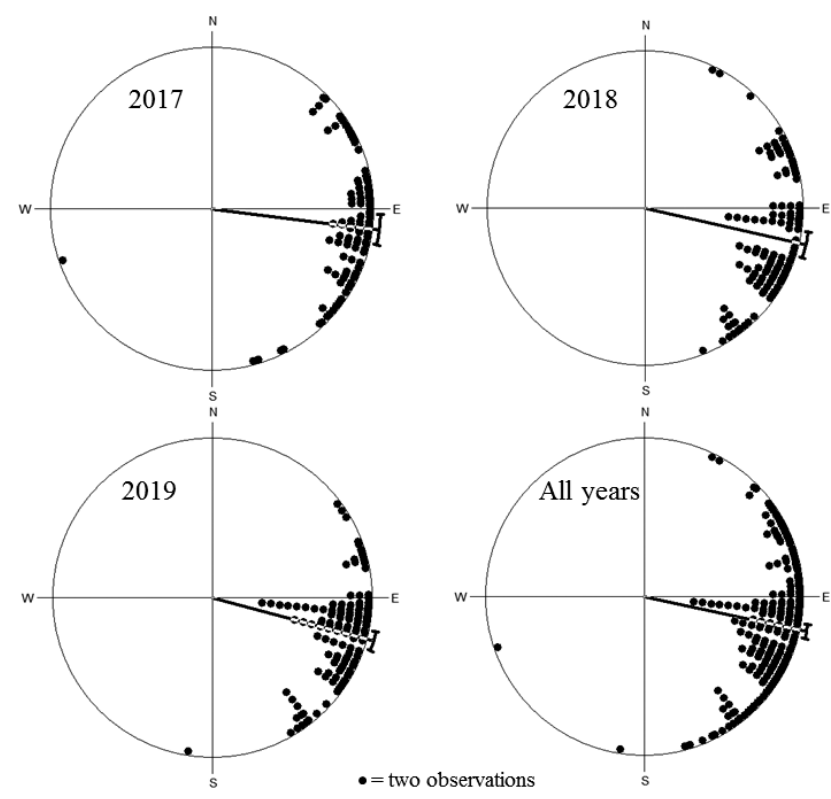

Fig. 4. Orientation of $P$. gallicus' nests recorded in this study.

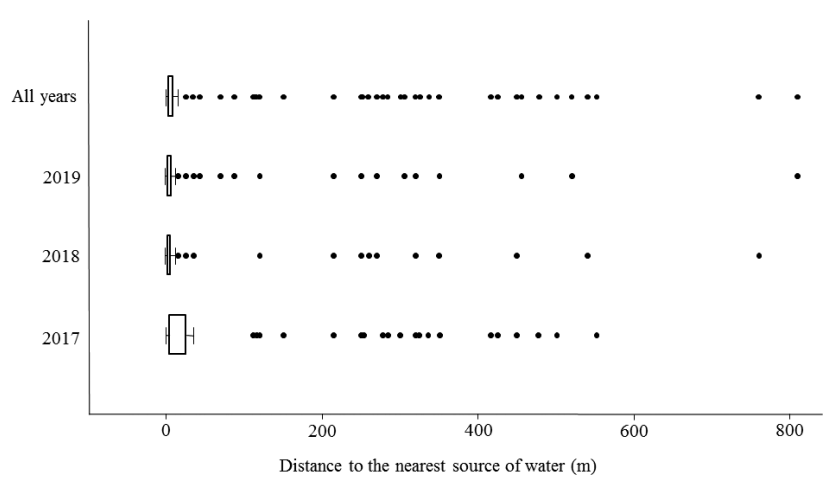

Fig. 5. Distances from nests to the nearest source of water at all the sites studied.

$\mathrm{m}$ (range: $0.3-802 \mathrm{~m}$ ) and did not differ between years (Mann-Whitney test, $\mathrm{U}=0.8959, \mathrm{p}=0.6422$ ).

At this study site, the number of foundresses per nest ranged between one to three. Exceptionally, we found a nest with seven foundresses. The overall ratio of multiple to single-foundress colonies was $47: 314$ for the three years studied. That is more single (104, 95 and 115 in 2017, 2018 and 2019, respectively) than multiple-foundress colonies (18, 11 and 18 in 2017, 2018 and 2019, respectively) were found.

Colony failure was higher in single than in multiplefoundress colonies: $35.03 \%$ of single-foundress colonies failed, whereas only $18.74 \%$ of the multiple-foundress colonies failed. The percentage survival of multiple-foundress nests was $83.33 \%, 54.54 \%$ and $94.44 \%$ in 2017,2018 and 2019 , respectively, whereas for single-foundress nests it was $67.30 \%, 50.52 \%$ and $74.78 \%$ in 2017,2018 and 2019 , respectively. None of the nests that had survived to the following year were reoccupied $(n=15)$.

\section{DISCUSSION}

As in birds (Mainwaring et al., 2014), prior to constructing a nest, the foundress of social wasps must decide on the location in which to construct it. The selection of a suitable nest site is determined by a combination of five main factors: the availability of food, risk of predation, presence and behaviour of conspecifics, availability of suitable nest material and a suitable ambient climate for raising offspring. Many studies have shown that wasps build nests in response to the environments they inhabit (Matsuura, 1990; Yamane, 1996; Hozymi \& Kudô, 2012) since the development of the immature stages depends on the ambient temperature. In Polistes, there is a clear relation between the nesting season and temperature (or latitude). In Mediterranean species, such as $P$. dominula, the length of the nesting seasons is between 6.5 and 7 months (Yamane, 1996). However, Höcherl \& Tautz (2015) report a mean nesting season of 4.6 months for this species in Germany (latitude $49^{\circ}$ ). The nesting season is even longer than that reported for this species in the United States (see Höcherl $\&$ Tautz, 2015). Thus, the duration of the nesting season at the site studied $\left(7.9\right.$ months, latitude $\left.38^{\circ}\right)$ cannot be considered as unusual. Zanette \& Field (2008) state that the nests of $P$. dominula appear in late winter (late February-March) 
in the south of Spain. Obviously, the nesting season can differ at the same place from year to year depending on temperature (Höcherl \& Tautz, 2015). These authors report nesting seasons ranging from 18 to 21 weeks over a period of three years for $P$. dominula. In $P$. gallicus, the nesting season ranged from 30 to 33 weeks from 2017 to 2019 .

Although we found colonies of $P$. gallicus in urban areas in the southwest of Spain, this study focused on natural populations. This study revealed that $P$. gallicus uses a wide variety of plants for nesting (48) in the south-west of Spain. There are no other similar studies for this species in this area or in its natural range. However, Kozyra et al. (2016) report $P$. nimpha constructs nests on 30 species of plants in Poland, which is similar to that reported for the same species in the Ukraine by Rusina \& Orlova (2011). In Italy, Cervo \& Turillazzi (1985) report that most of the nests $(76 \%)$ of $P$. gallicus were on Ditrichia (=Inula) vis$\cos a$ (Asteraceae).

Why a wasp selects a given plant is unclear, and several factors may affect the choice: (a) The availability of plants when foundresses emerge in late winter. Kozyra et al. (2016) state that at the end of winter the only available nesting sites for wasps are young trees, shrubs, lignified parts of herbaceous plants, or grass culms remaining after the winter period. However, in early winter in the south of Spain (with warmer winters than in Poland), some shrubs and herbaceous plants can be utilised by wasps to build their nests, as is the case of Diplotaxis plants or some Asteraceae plants. (b) Protection. At the site studied, approximately one third $(33.33 \%)$ of the plants selected by wasps had some form of passive defence (spines, thorns). The most selected species of plant in this study was Scirpoides holoschoenus, a perennial plant with pointed stems. In addition, we did not find nests on isolated plants. This means that plants surrounding nests may provide protection against high temperatures by shading and thus prevent overheating in the warmest weeks of the colony cycle. (c) Occultation/camouflage. As in P. dominula and P. nimpha, the colour of the nests of $P$. gallicus is beige and grey, with dark grey linings (Bagriaçik, 2012). This pattern may serve to camouflage the nest on most of the plants selected by wasps, especially in late spring and summer, when most plants dry out because of high temperatures. (d) Nest consistency. The nest of Polistes is made of chewed plant fibres from weathered wood and other sources (Jeanne, 1975). It is also known that species of Polistes prefer long vegetative fibres and plant hairs for nest material (Bagriaçik, 2012). This author reports that the nests of $P$. gallicus are less consistent, smaller and lighter than those of $P$. dominula and $P$. nimpha. Cole at al. (2001) report differences in the nests of the three vespine wasps (Vespa vulgaris, Dolichovespula norwegica, and D. sylvestris), namely in the types of fibres used to build the comb and envelope of their nests. These authors attribute these differences to the use of different sources of pulp to build their nests. (e) Protection against parasitoids. Parasitoids are a major cause of mortality in many insects (Godfray, 1994), including wasps (Rusina, 2008).
In this study, nest height $(21-181 \mathrm{~cm})$ was higher than that reported for $P$. nimpha in Poland (15-25 cm, Kozyra et al., 2016) and Italy (4-60 cm, Cervo \& Turillazzi, 1985). Plant growth is influenced by a variety of external and internal factors. The former include light, temperature, water, nutrients, etc., while the latter include genetic and hormonal factors. Hence, it is not surprising that there are differences between Polish and Spanish plants. We even found significant differences in plant height from year to year, probably caused by differences in rainfall. Nest height does not depend on plant species and is not accidental. However, we agree with Kozyra et al. (2016) that nest height plays an important role in protecting the nest from predators. We suppose, as occurs in birds (Mainwaring et al., 2014), they build their nests at varying heights in response to predators, higher from the ground in response to mammalian and ant predators and lower in response to avian predators.

In many social insects, such as ants and termites, the geographic orientation of the nests is not accidental and is of great significance for their thermoregulation (Jones \& Oldroyd, 2007). Nest orientation often influences the amount of solar radiation absorbed by a nest and the time of day that the highest level of radiation is received. Many species orientate their nests so that it is warmed by solar radiation in the cool of the morning (Jones \& Oldroyd, 2007). The nest orientation of $P$. gallicus in our study $\left(102.11^{\circ}\right)$ is very similar to that reported for P. nimpha in Poland $\left(110^{\circ}\right.$, Kozyra et al., 2016) and Italy (162 ${ }^{\circ}$, Cervo \& Turillazzi, 1985 ) and agrees with that reported by Yamane (1996) for $P$. snellini and P. biglumis (on southern and south-eastern slopes).

Water is a limiting factor for the development of wasps (Horwood et al., 1993) and is required for temperature control (Greene, 1991), nest construction (Jeanne, 1996) and metabolism (Richter, 2000). To overcome the desiccation associated with their habitats, insects have adopted several physiological and behavioural practices (Kovac et al., 2009), such as living in more favourable microhabitats (Benoit et al., 2007), foraging in more protected areas (Hu et al., 2012) and making frequent trips to sources of moisture (Willmer, 1986). Building a nest near a water source may be advantageous for colony development if we consider that the collection of liquids may make up $80 \%$ of the material collected by some vespids. In this study, the mean distance of nests from sources of water (small temporary rivers in most cases) was $43.51 \mathrm{~m}$. Assuming a flight range of $250 \mathrm{~m}$ for species of Polistes (see Prezoto \& Gobbi, 2005), only $9.61 \%$ of the nests analysed were located at distances greater than $250 \mathrm{~m}$. This indicates that in the south-west of Spain, $P$. gallicus nest close to sources of water, confirming the importance of this resource for these wasps. Another advantage of building a nest near a source of water is related to thermoregulation. Polistes wasps build exposed combs, without any cover and protection. Because of this, the thermoregulation of their nests depends mainly on environmental conditions (Höcherl et al., 2016). The passive mechanisms of thermoregulation include all those that help to optimise the internal temperatures, such as site 
selection. Nest-site selection plays a major role in the ability of social insect colonies to maintain stable nest temperatures. Nest-site choice falls into two broad categories. For many species, the main criterion when selecting a nest site is physical protection against environmental perturbations; others select sites where the microclimate provides a relatively stable temperature (Jones \& Oldroyd, 2007). In the south of Spain, where the summers are hot, the patches of vegetation surrounding small rivers or streams may function as temperature islands. Thus, by nesting in these patches of vegetation the wasps may reduce the heating load on their nests and avoid extreme temperatures in July and August.

As a primitive species of eusocial wasp, the cooperation of queens in nest building and brood care in Polistes is common (Reeve, 1991). We recorded a maximum of seven foundresses per nest in this study, which is similar to that recorded in other studies. For instance, Zanette \& Field (2009) records $P$. dominula wasp nests built by $1-10$ foundresses in Southern Spain. In this study, we recorded more single than multiple foundation colonies for P. gallicus. For $P$. dominula, Turillazzi et al. (1982) report 36\% single and $64 \%$ multiple-foundress colonies, respectively and Zanette \& Field (2011) 7\% single and 93\% multiple-founded nests, respectively. However, in Germany (Höcherl \& Tautz, 2015), the percentage of the colonies established by hibernating queens of $P$. dominula, multiple and single founded are similar (46\% and 54\%, respectively). One of the advantages of multiple founding is that the percentage survival of these nests is greater than that of single founded nests. Our results confirm this and agree with the reports of Höcherl \& Tautz (2015). Another benefit of multiple-foundress nests is increased productivity, measured in terms of the number of cells per nest (Queller et al., 2000; Tibbetts \& Reeve, 2003). However, Höcherl \& Tautz (2015) report that the mean number of cells per nest is not significantly different between single and multiple-founded colonies in Germany.

ACKNOWLEDGEMENTS. CMR was supported by a Departmental collaboration grant (Ministry of Education, Spanish Government).

\section{REFERENCES}

BAgriaçIK N. 2012: Comparison of nest materials of Polistes gallicus (L.), Polistes dominulus (Christ) and Polistes nimpha (Christ) (Hymenoptera: Vespidae). — Arch. Biol. Sci. 64: 1079-1084.

Batschelet E. 1981: Circular Statistics in Biology. Academic Press, New York, NY, 371 pp.

Benoit J.B., Lopez-Martinez G., Elnitsky M.A., Lee R.E. \& DeNLINGER D. 2007: Moist habitats are essential for adults of the Antarctic midge, Belgica antarctica (Diptera: Chironomidae), to avoid dehydration. - Eur. J. Entomol. 104: 9-14.

CANT M.A., Llop J.B. \& Field J. 2006: Individual variation in social aggression and the probability of inheritance: theory and a field test. - Am. Nat. 167: 837-852.

Capel Molina J.J. 1981: Los Climas de España. Oikos-Tau, Barcelona, $429 \mathrm{pp}$.

Castroviejo S. (CoOr. Gen.) 1986-2012: Flora iberica 1-8, 10 15, 17-18, 21. Real Jardín Botánico, CSIC, Madrid.
Cervo R. \& Turillazzi S. 1985: Associative foundation and nesting sites in Polistes nimpha. - Naturwissenschaften 72: 48-49.

Cole M.R., Hansell H.H. \& Seath C.J. 2001: A quantitative study of the physical properties of nest paper in three species of Vespinae wasps (Hymenoptera, Vespidae). - Insectes Soc. 48: 33-39.

Collinge S.K., Prudic K.L. \& Oliver J.C. 2003: Effects of local habitat characteristics and landscape context on grassland butterfly diversity. - Conserv. Biol. 17: 178-187.

Gamboa G.J., Austin J.A. \& Monnet K.M. 2005: Effects of different habitats on the productivity of the native paper wasp Polistes fuscatus and the invasive, exotic paper wasp P. dominulus (Hymenoptera: Vespidae). — Great Lakes Entomol. 38: 170-176.

Gayubo S.F. \& TorRes F. 1990: Efecto de la presión urbana sobre abejas y avispas (Hymenoptera, Aculeata) en Salamanca. III: Eumenidae y Vespidae. - Studia Oecol. 7: 101-116.

Godfray H.C.J. 1994: Parasitoids: Behavioral and Evolutionary Ecology. Princeton University Press, Princeton, NJ, 473 pp.

Greene A. 1991: Dolichovespula and Vespula. In Ross K.G. \& Matthews R.W. (eds): The Social Biology of Wasps. Cornell University Press, Ithaca, NY, pp. 263-305.

HeInRICH B. 1993: The Hot-Blooded Insects: Strategies and Mechanisms of Thermoregulation. Harvard University Press, Cambridge, MA, 612 pp.

HöCherl N. \& TAUTZ J. 2015: Nesting behaviour of the paper wasp Polistes dominula in Central Europe - a flexible system for expanding into new areas. - Ecosphere 6(12): 262, $11 \mathrm{pp.}$

Höcherl N., Kennedy S. \& Tautz J. 2016: Nest thermoregulation of the paper wasp Polistes dominula. $-J$. Therm. Biol. 60: $71-179$.

Horwood M.A., Toffolon R.B. \& Brown G.R. 1993: Establishment and spread of Vespula germanica (F.) (Hymenoptera: Vespidae) in New South Wales and the influence of rainfall on its abundance. - J. Aust. Entomol. Soc. 32: 241-248.

Hozymi S. \& Kudô K. 2012: Adaptive nesting tactics in a paper wasp, Polistes riparius, inhabiting cold climatic regions. - Sociobiology 59: 1447-1458.

Hu J., Neoh K.B., Appe A.G. \& Lee C.Y. 2012: Subterranean termite open-air foraging and tolerance to desiccation: comparative water relation of two sympatric Macrotermes spp. (Blattodea: Termitidae). - Comp. Biochem. Physiol. 161: 201-207.

Inagawa K., Kojima J., Sayama K. \& Tsuchida K. 2001: Colony productivity of the paper wasp Polistes snelleni: comparison between cool-temperate and warm-temperate populations. Insectes Soc. 48: 259-265.

JEANNE R.L. 1975: The adaptiveness of social wasp nest architecture. - Quart. Rev. Biol. 50: 267-286.

JEANNE R.L. 1996: Regulation of nest construction behavior in Polybia occidentalis. - Anim. Behav. 52: 473-488.

Jones J.J. \& OldRoyd B.P. 2007: Nest thermoregulation in social insects. - Adv. Insect Physiol. 33: 153-191.

KASUYA E. 1982: Central place water collection in a Japanese paper wasp, Polistes chinensis antennalis. - Anim. Behav. 30: 1010-1014.

Kovac H., Stabentheiner A. \& Schmaranzer S. 2009: Termoregulation of water foraging wasps (Vespula vulgaris and Polistes dominulus). - J. Insect Physiol. 55: 959-966.

Kovach W.L. 2011: Oriana. Circular Statistics for Windows. Ver. 4. Kovach Computing Services, Pentraeth, Wales, U.K.

Kozyra K.B., BaraniaK E. \& Kasprowicz M. 2016: Nesting ecology of Polistes nimpha (Hymenoptera, Vespidae): a preliminary study in western Poland. - J. Hymenopt. Res. 51: $187-201$. 
Leadbeater E., Carruthers J.M., Green J.P., van Heusden J. \& FIELD J. 2010: Unrelated helpers in a primitively eusocial wasp: Is helping tailored towards direct fitness? - PLOS ONE 5(8): e11997, 7 pp.

Mainwaring M.C., Hartley I.R., Lambrechts M.M. \& Deeming C. 2014: The design and function of birds' nests. - Ecol. Evol. 20: 3909-3928.

Martin T.E. \& Roper J. 1988: Nest predation and nest-site selection of a western population of the hermit thrush. - The Condor 90: 51-57.

Matsuura M. 1990: Biology of three Vespa species in central Sumatra (Hymenoptera, Vespidae). In Sakagami F.S., Ohgushi R. \& Roubik D.W. (eds): Natural History of Social Wasps and Bees in Equatorial Sumatra. Hokkaido University Press, Sapporo, pp. 113-124.

Nadeau H. \& Stamp N. 2003: Effect of prey quantity and temperature on nest demography of social wasps. - Ecol. Entomol. 28: 328-339.

Prezoto F. \& GobBi N. 2005: Flight range extension in Polistes simillimus Zikán, 1951 (Hymenoptera, Vespidae). — Braz. Arch. Biol. Technol. 48: 947-950.

Queller D.C., Zacchi F., Cervo R., Turillazzi S., Henshaw M.T., SANTORELli L.A. \& StRASSMANN J.E. 2000: Unrelated helpers in a social insect. - Nature 405: 784-787.

Raunkiaer C. 1934: The Life Forms of Plants and Statistical Plant Geography. Oxford University Press, London, 721 pp.

RaVeret M. 2000: Social wasps (Hymenoptera: Vespidae) foraging behavior. - Annu. Rev. Entomol. 45: 121-150.

ReEve H.K. 1991: Polistes. In Ross K.G. \& Matthews R.W. (eds) The Social Biology of Wasps. Cornell University Press, Ithaca, NY, pp. 99-148.

RichTER M.R. 2000: Social wasp (Hymenoptera: Vespidae) foraging behavior. - Annu. Rev. Entomol. 45: 121-150.

Rоoт R.B. 1973: Organization of a plant-arthropod association in simple and diverse habitats-fauna of collards (Brassica oleracea). - Ecol. Monogr. 43: 95-120.

Rusina L.Yu. 2006: Polistine Wasps in Natural and Anthropogenic Landscapes of the Lower Dnieper Area. KSU, Kherson, 200 pp. [in Russian].

Rusina L.Yu. 2008: Reaction of parasitoids of the paper wasp Polistes dominulus (Christ) (Hymenoptera, Vespidae, Polistinae) to the host distribution. - Entomol. Rev. 88: 881-897.
Rusina L.Yu. 2009: Structure and functional organization of Polistes wasps populations (Hymenoptera, Vespidae). - Proc. Russ. Entomol. Soc. 79: 217 pp. [in Russian, with English abstr.].

Rusina L.Yu. \& OrLova E.S. 2011: The relationship between phenotypic variability in future foundresses of Polistes nimpha (Christ) (Hymenoptera, Vespidae, Polistinae) and infestation of their larvae by the mite Sphexicozela connivens Mahunka (Acari, Astigmata, Winterschmidtiidae). - Entomol. Rev. 91: 685-691.

Schmid-Egger C., van Achterberg K., Neumayer R., Morinière J. \& Schmidt S. 2017: Revision of the West Palaearctic Polistes Latreille, with the descriptions of two species - an integrative approach using morphology and DNA barcodes (Hymenoptera, Vespidae). - ZooKeys 713: 53-112.

Steiner A. 1930: Die Temperaturregulierung im Nest der Feldwespe (Polistes gallica var. biglumis L.). - Z. Vergl. Physiol. 11: 461-502.

Tibbetts E.A. \& Reeve H.K. 2003: Benefits of foundress associations in the paper wasp Polistes dominulus: increased productivity and survival, but no assurance of fitness returns. Behav. Ecol. 14: 510-514.

Turillazzi S., Marino-Piccioli M.T., Hervatin L. \& Pardi L. 1982: Reproductive capacity of single foundress and associated foundress females of Polistes gallicus (L.) (Hymenoptera Vespidae). - Monit. Zool. Ital. (N.S.) 16: 75-88.

WILLMER P.G. 1986: Foraging patterns and water balance: problems of optimization for a xerophilic bee, Chalicodoma sicula. - J. Anim. Ecol. 55: 941-962.

YAMANE S. 1996: Ecological factors influencing the colony cycle of Polistes wasps. In Turillazzi S. \& West-Eberhard M.J. (eds): The Natural History and Evolution of Paper Wasps. Oxford University Press, London, pp. 75-97.

ZANetTe L.R.S. \& Field J. 2008: Genetic relatedness in early associations of Polistes dominulus: from related to unrelated helpers. - Mol. Ecol. 17: 2590-2597.

ZANETTE L.R.S. \& Field J. 2009: Cues, concessions, and inheritance: dominance hierarchies in the paper wasp Polistes dominulus. - Behav. Ecol. 20: 773-780.

ZANETTE L.R.S. \& FieLD J. 2011: Founders versus joiners: group formation in the paper wasp Polistes dominulus. - Anim. Behav. 82: 699-705.

Received November 25, 2019; revised and accepted April 23, 2020 Published online May 13, 2020 